\title{
Технологические подходы к созданию мозаичных фотоприемников сверхвысокой размерности с предельной эффективностью преобразования изображений
}

\author{
А.И. Козлов ${ }^{1)}$, А.Р. Новоселов ${ }^{2)}$ \\ ${ }^{1}$ Институт физики полупроводников им. А.В. Ржанова СО РАН, \\ Новосибирск, 630090, пр. Ак. Лаврентьева, 13 \\ ${ }^{2}$ Новосибирский филиал ИФП СО РАН “Конструкторско-технологический институт прикладной \\ микроэлектроники” (КТИПМ), \\ Новосибирск, 630090, пр-т Акад. Лаврентьева, 2/1
}

тел: +7 (383) 333-1957, факс: +7 (383) 333-2771, эл. почта: kozlov@isp.nsc.ru

DOI 10.34077/RCSP2019-152

Потребность увеличения пространственного разрешения тепловизионных систем стимулирует создание фотоприемников сверхвысокой размерности для соответствующих спектральных диапазонов. Прямое увеличение количества фоточувствительных элементов (ФЧЭ) в фотоприемнике ведет к значительному увеличению площади кристаллов кремниевых мультиплексоров (КМ) и матрицы ФЧЭ. При увеличении площади кристаллов уменьшается выход годных изделий, что непосредственно определяет высокую стоимость приборов [1].

Мозаичная технология является одним из перспективных технических решений кардинального увеличения форматов приемников. Мозаичные фотоприемники (МФП) создают посредством

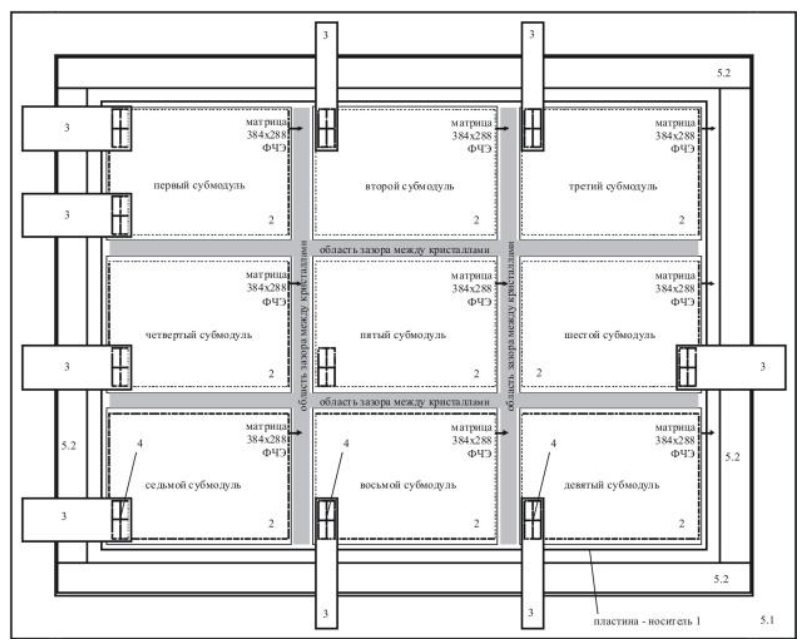
технологии микросборки субмодулей приемлемого для изготовления формата. Основной проблемой МФП являются "слепые зоны" - области вдоль линий стыковки смежных субмодулей, в которых отсутствуют ФЧЭ [1].

Поисковые научные исследования, направленные на создание мозаичной технологии приемников сверхвысокой размерности для инфракрасного (ИК) и терагерцового (ТГц) диапазонов, обеспечили развитие технологических подходов к изготовлению МФП с предельной эффективностью преобразования изображений. Один из перспективных способов создания МФП заключается в том, что фотоприемные субмодули (2) устанавливают на заданные места пластиныносителя (1) внутри опорной прямоугольной рамки (5.1), внутренние размеры которой соответствуют размерам МФП (рис.); фиксацию всех субмодулей осуществляют одновременно, подачей вакуума к отверстиям в пластине-носителе для самосовмещения и позиционирования кристаллов при затвердевании слоев удерживающего материала под субмодулями; формирование внутренних граней опорной прямоугольной рамки выполняют прецизионно, с обеспечением шероховатости не более 1 мкм [1].

Полученные результаты могут увеличить точность позиционирования субмодулей в составе МФП, повысить технологичность способа изготовления МФП, упростить технологию изготовления, уменьшить трудоемкость изготовления и снизить стоимость МФП.

\section{Литература}

[1] Козлов А.И., Новоселов А.Р. и др. Оптический журнал. 2018. Т.85, №2. С.60-66.

[2] Козлов А.И., Демьяненко М.А. и др. Автометрия. 2016. Т.52, №2. С.115-121. 